Article

\title{
Efficacy and Safety of Sitafloxacin in the Treatment of Acute Bacterial Infection: A Meta-analysis of Randomized Controlled Trials
}

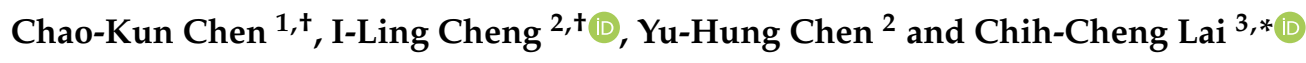 \\ 1 Department of Surgery, Chi Mei Medical Center, Tainan 73657, Taiwan; a.kun.ke@gmail.com \\ 2 Department of Pharmacy, Chi Mei Medical Center, Liouying, Tainan 73657, Taiwan; \\ bokey1010@gmail.com (I.-L.C.); her0windqoo@gmail.com (Y.-H.C.) \\ 3 Department of Internal Medicine, Kaohsiung Veterans General Hospital, Tainan Branch, \\ Tainan 73657, Taiwan \\ * Correspondence: dtmed141@gmail.com \\ + The two authors contributed equally.
}

Received: 20 January 2020; Accepted: 28 February 2020; Published: 2 March 2020

\begin{abstract}
This meta-analysis aimed to assess the efficacy and safety of sitafloxacin in treating acute bacterial infection. PubMed, Embase, and Cochrane databases were searched up to August 13, 2019. Only randomized controlled trials (RCTs) evaluating sitafloxacin and comparators in the treatment of acute bacterial infections were included. The outcomes were clinical and microbiological responses and the risk of adverse event (AE). Five RCTs were enrolled, including 375 and 381 patients who received sitafloxacin and the comparator, respectively. Overall, the clinical response rate of sitafloxacin in the treatment of acute bacterial infections was $94.6 \%$, which was noninferior to that of the comparator $\left(92.5 \%\right.$ ) (odds ratio (OR), 1.01; 95\% CI, 0.24-4.32; $I^{2}=66 \%$ ). For patients with complicated urinary tract infection (cUTI)/acute pyelonephritis (APN), the clinical response rate of sitafloxacin and the comparator was $96.9 \%$ and $91.3 \%$, respectively (OR, 2.08; 95\% CI, 0.35-12.44; $I^{2}=54 \%$ ). For patients with pneumonia, the clinical response rate of sitafloxacin was $88.6 \%$, which was comparable to that of the comparator (OR, $\left.0.36 ; 95 \% \mathrm{CI}, 0.11-1.21 ; I^{2}=0 \%\right)$. The microbiological response of sitafloxacin was $82.0 \%$, which was noninferior to that of the comparator $(77.8 \%)(\mathrm{OR}, 1.59$; $95 \%$ CI, 0.77-3.28; $I^{2}=47 \%$ ). The risk of treatment-emergent adverse event (TEAE), drug-related TEAE, and all-cause mortality were similar between sitafloxacin and the comparators (TEAE, OR, 1.14; 95\% CI, 0.64-2.01, drug-related TEAE, OR, 1.14; 95\% CI, 0.48-2.69, mortality, OR, 0.93; 95\% CI, 0.09-9.44). In conclusion, sitafloxacin is noninferior to other commonly used antibiotics with respect to both clinical and microbiological response rates in patients with an acute bacterial infection, including cUTI/APN and pneumonia. In addition, sitafloxacin is also as safe as the comparators.
\end{abstract}

Keywords: sitafloxacin; acute bacterial infection; complicated urinary tract infection; acute pyelonephritis; pneumonia

\section{Introduction}

Sitafloxacin is a new generation fluoroquinolone that exhibits excellent in vitro activity against many Gram-positive, Gram-negative, anaerobic bacteria, and atypical pathogens. Moreover, it remains active against the strains resistant to other fluoroquinolones [1]. For commonly encountered bacteria, the activity of sitafloxacin against Gram-positive cocci, including Streptococcus pneumoniae, Streptococcus pyogenes, Enterococcus faecalis, and methicillin-susceptible Staphylococcus aureus was comparable or superior to those of garenoxacin, moxifloxacin and levofloxacin [2]. In addition, sitafloxcain showed the more potent activity against Gram-negative bacteria, including Escherichia coli, Hemophilus influenzae, 
Moraxella catarrhalis, Enterobacteriaceae, and Pseudomonas aeruginosa and anaerobic bacteria other than fluoroquinolones-garenoxacin, moxifloxacin, and levofloxacin [2]. For atypical bacteria, the minimum inhibitory concentration (MIC) of sitafloxacin at which $90 \%$ of isolates $\left(\mathrm{MIC}_{90}\right.$ ) against Mycoplasma pneumoniae, was $0.03 \mu \mathrm{g} / \mathrm{mL}$, which was 4 - and 16-fold more active than moxifloxacin and levofloxacin, respectively [3]. MIC $90_{90}$ of sitafloxacin against Legionella pneumophila was $0.004 \mu \mathrm{g} / \mathrm{mL}$, which was 2and 4-fold more active than levofloxacin and moxifloxacin, respectively [3]. Even for a multidrug resistant organism, such as the carbapenem-resistant Acinetobacter baumannii complex, sitafloxacin had a significantly lower MIC in comparison with ciprofloxacin and levofloxacin, and the rate of resistance to sitafloxacin was significantly lower than that to ciprofloxacin and levofloxacin [4]. All these findings indicate that sitafloxacin has great activity against these commonly encountered pathogens in the clinical entity of respiratory tract infection and urinary tract infection and further suggests that sitafloxacin could be a promising antibiotic in the treatment of acute bacterial infection.

Sitafloxacin has been used in the treatment of respiratory tract infection and urinary tract infection in Japan for decades, and it has become available in Thailand since 2012. However, only limited studies have investigated the clinical efficacy of sitafloxacin in the treatment of pneumonia and urinary tract infections [5-11]. To provide better evidence of the efficacy and safety of sitafloxacin on treating acute bacterial infections, we conducted this comprehensive and updated meta-analysis.

\section{Methods}

\subsection{Study Search and Selection}

A systematic review of the literature in PubMed, Embase, and Cochrane databases was conducted using the following search terms: "sitafloxacin," "randomized," and "randomised", until August 13, 2019. We only included randomized controlled trials (RCT) that investigated the clinical efficacy and safety of sitafloxacin and other comparators for treating acute bacterial infections. The single-arm study, case series, or cohort studies, pharmacokinetic studies, or in vitro studies and studies focusing on drug toxicity were excluded. Authorship, publication year, study sites, antibiotic regimens, clinical and microbiological outcomes, and adverse events (AEs) were extracted from the included studies.

\subsection{Definition and Outcome}

The intention-to-treat (ITT) population was defined as subjects who had acute bacterial infection according to the inclusion criteria for clinical trial and received any amount of the study drug. The clinically evaluable (CE) population was defined as the ITT population who had an available outcome assessment. The microbiologically evaluable (ME) population was defined as the CE population, in which at least one bacterial pathogen was isolated at baseline.

The primary outcome was measured as the clinical response at the end of treatment (EOT) and test of cure (TOC) visit among the ITT and the CE population. Clinical response was defined as the resolution or improvement of clinical signs and symptoms of acute bacterial infection, and no further antimicrobial therapy was needed. We also measured microbiological response and the risk of AEs as secondary outcomes.

\subsection{Data Analysis}

This risk of bias of enrolled RCTs was evaluated by the Cochrane Risk of Bias Assessment Tool [12]. We used the random effect model of the software Review Manager, version 5.3, to conduct statistical analyses. The outcome analysis was calculated using the pooled odds ratio (OR) and $95 \%$ confidence intervals (CIs). 


\section{Results}

\subsection{Study Selection and Characteristics}

The initial literature search identified 1293 studies from PubMed $(\mathrm{n}=317)$, Embase $(\mathrm{n}=912)$, and the Cochrane database $(n=64)$. After excluding 322 duplicated articles, the remaining 971 articles were screened using the title and abstract. Finally, a total of five studies were enrolled after full-text screening (Figure 1). Among them, four studies carried a high risk of performance and detection bias (Figure 2). In total, five RCTs [5,7-9,11] fulfilling the inclusion criteria were enrolled in this meta-analysis (Table 1) [5,7-9,11]. Except for one study [8], all the others [5,7,9,11] were multicenter studies. Three studies $[7,8,11]$ focused on complicated urinary tract infection (cUTI)/acute pyelonephritis (APN), and two [5,9] focused on pneumonia. Overall, each of the 375 and 381 patients received sitafloxacin and the comparator, respectively. One study [5] used sitafloxacin in the intravenous form, and four studies [7-9,11] used sitafloxacin in the oral form. However, the dosage of sitafloxacin varied and ranged from $100 \mathrm{mg}$ per day to $400 \mathrm{mg}$ per day. The comparative agents also varied in each study and included imipenem [5], ertapenem [8], levofloxacin [11], garenoxacin [9], and ceftriaxone/cefdinir [7].
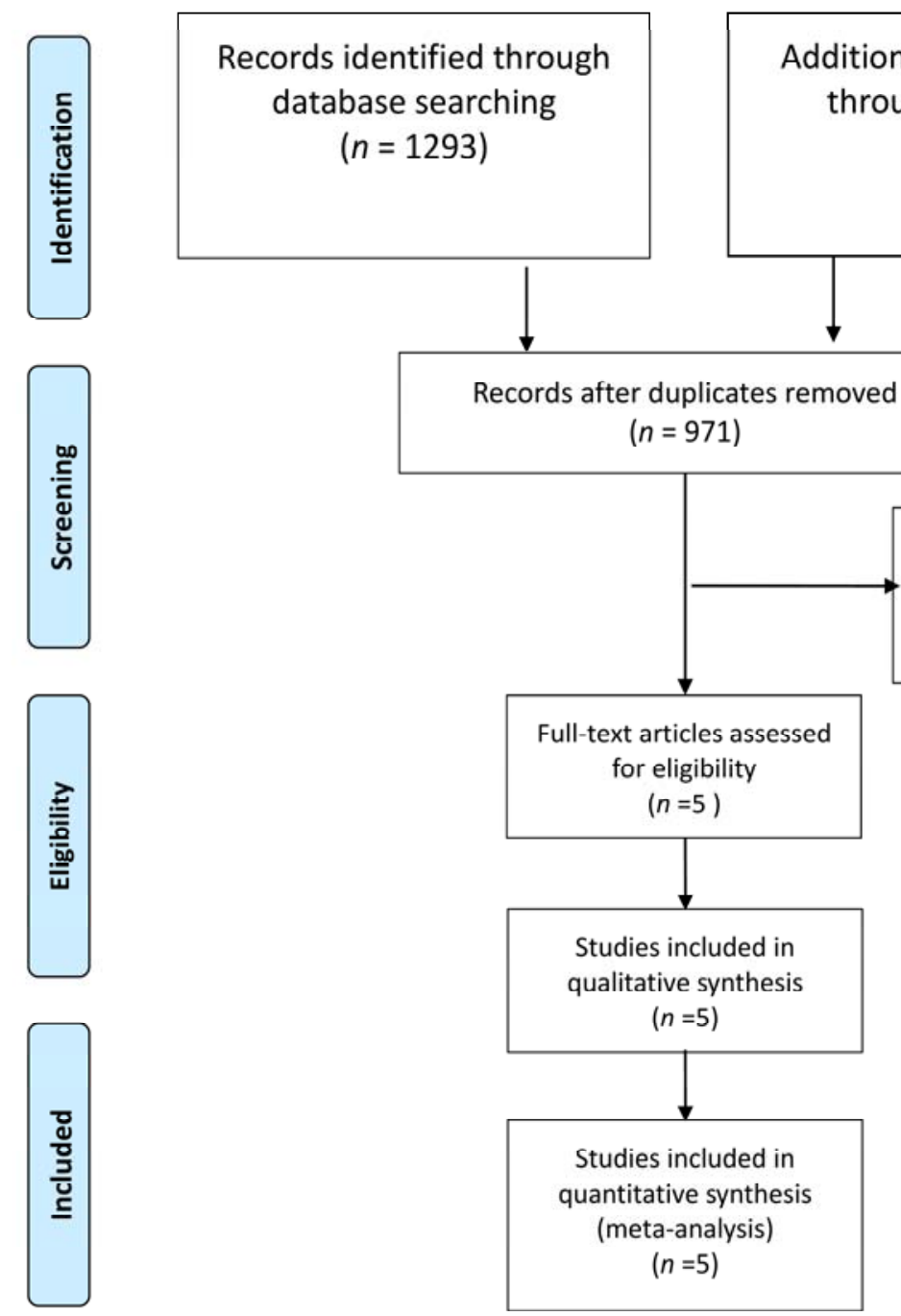

Records excluded non randomized controlled trials, pharmacokinetics, in vitro susceptibility testing or experimental animal studies $(n=966)$

Figure 1. The flow-chart of study selection. 


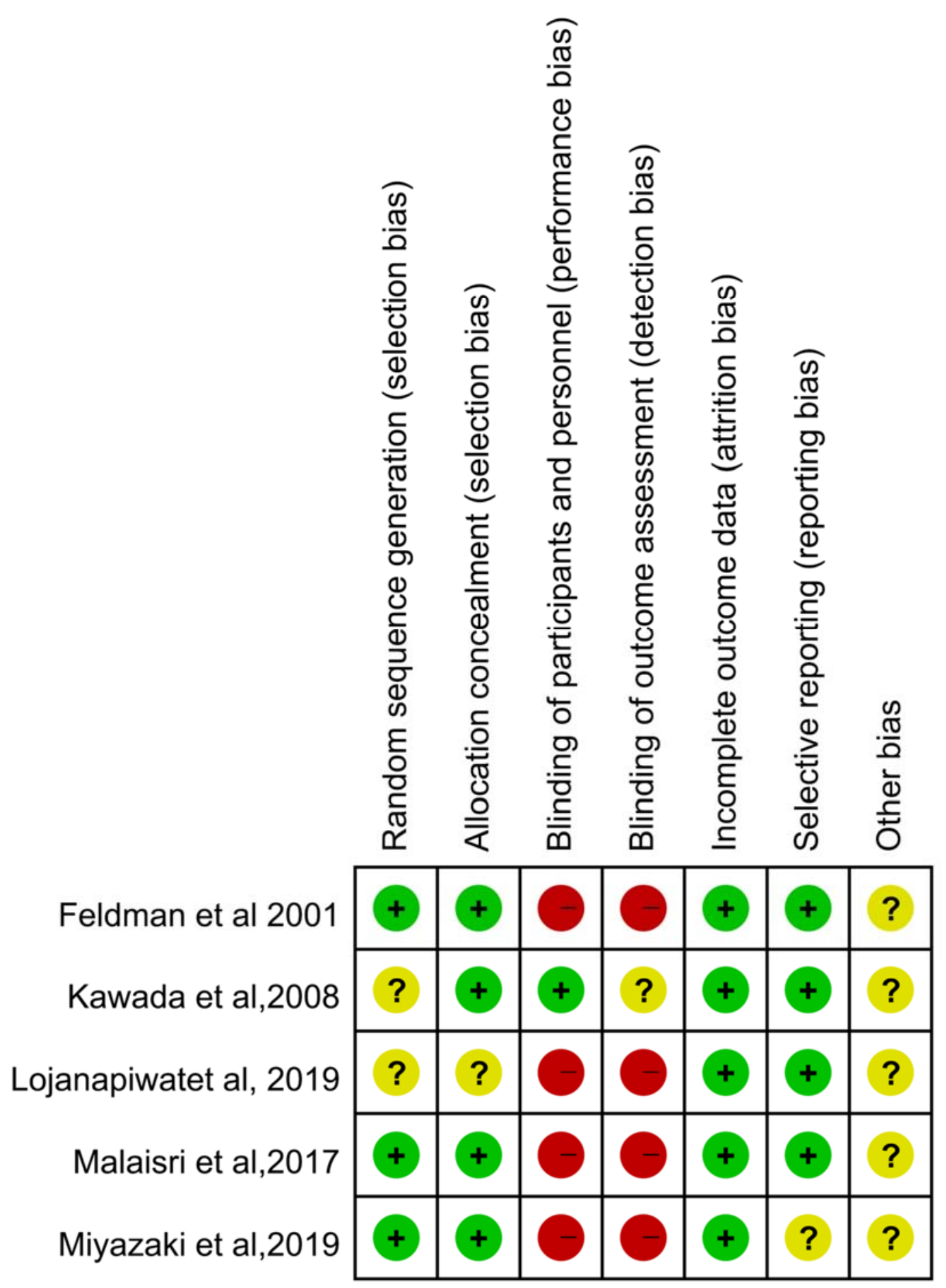

Figure 2. The summary of risk of bias. 
Table 1. Summary of the characteristics of enrolled studies in the meta-analysis.

\begin{tabular}{|c|c|c|c|c|c|c|c|c|}
\hline \multirow{2}{*}{$\begin{array}{c}\text { Study, } \\
\text { Published Year }\end{array}$} & \multirow{2}{*}{ Study Design } & \multirow{2}{*}{ Study Site } & \multirow{2}{*}{ Study Period } & \multirow{2}{*}{$\begin{array}{c}\text { Study } \\
\text { Population }\end{array}$} & \multicolumn{2}{|c|}{ No of Patients (ITT Population) } & \multicolumn{2}{|c|}{ Dose regimen } \\
\hline & & & & & Sitafloxacin & Comparator & Sitafloxacin & Comparator \\
\hline $\begin{array}{l}\text { Feldman et al., } \\
2001\end{array}$ & $\begin{array}{c}\text { phase II, } \\
\text { randomized, } \\
\text { open-label, } \\
\text { parallel trial }\end{array}$ & $\begin{array}{l}10 \text { centers in three } \\
\text { countries }\end{array}$ & NA & $\begin{array}{l}\text { Acute bacterial } \\
\text { pneumonia } \\
\text { requiring } \\
\text { hospitalization }\end{array}$ & 35 & 34 & $\begin{array}{c}\text { Intravenous } \\
\text { sitafloxacin } 400 \\
\text { mg qd }\end{array}$ & Imipenem 500 mg q8h \\
\hline $\begin{array}{c}\text { Kawada et al., } \\
2008\end{array}$ & $\begin{array}{c}\text { randomized } \\
\text { double-blind trial }\end{array}$ & 58 hospitals in Japan & 1998-2000 & $\begin{array}{l}\text { Complicated } \\
\text { urinary tract } \\
\text { infection }\end{array}$ & 122 & 121 & $\begin{array}{l}\text { Oral sitafloxacin } \\
50 \mathrm{mg} \text { b.i.d }\end{array}$ & $\begin{array}{c}\text { Oral levofloxacin } 100 \mathrm{mg} \\
\text { t.i.d }\end{array}$ \\
\hline $\begin{array}{c}\text { Malaisri et al., } \\
2017\end{array}$ & $\begin{array}{l}\text { prospective, } \\
\text { open-label, } \\
\text { randomized, } \\
\text { controlled trial }\end{array}$ & $\begin{array}{l}\text { Single hospital in } \\
\text { Thailand }\end{array}$ & 2012-2015 & $\begin{array}{c}\text { Acute } \\
\text { pyelonephritis } \\
\text { caused by ESBL } \\
\text { E. coli }\end{array}$ & 19 & 17 & $\begin{array}{l}\text { Oral sitafloxacin } \\
100 \text { mg bid } \\
\text { followed by } \\
\text { initial 3-day } \\
\text { carbapenem }\end{array}$ & $\begin{array}{c}\text { Intravenous ertapenem } 1 \\
\text { g qd followed by initial } \\
\text { 3-day carbapenem }\end{array}$ \\
\hline $\begin{array}{l}\text { Lojanapiwat et } \\
\text { al., } 2019\end{array}$ & $\begin{array}{l}\text { prospective, } \\
\text { open-label, } \\
\text { randomized, } \\
\text { controlled, } \\
\text { noninferiority, } \\
\text { clinical trial }\end{array}$ & $\begin{array}{l}9 \text { medical centers in } \\
\text { Thailand }\end{array}$ & 2013 to $2015^{9}$ & $\begin{array}{c}\text { Acute } \\
\text { pyelonephritis } \\
\text { or complicated } \\
\text { urinary tract } \\
\text { infection }\end{array}$ & 141 & 148 & $\begin{array}{l}\text { Oral sitafloxacin } \\
100 \mathrm{mg} \text { bid }\end{array}$ & $\begin{array}{c}\text { Intravenous ceftriaxone } 2 \\
\text { g qd x } 2-3 \text { days, followed } \\
\text { by oral cefdinir } 100 \mathrm{mg} \\
\text { q8h }\end{array}$ \\
\hline $\begin{array}{l}\text { Miyazaki et al., } \\
2019\end{array}$ & $\begin{array}{c}\text { randomized, } \\
\text { open-label clinical } \\
\text { trial }\end{array}$ & $\begin{array}{l}11 \text { medical centers or } \\
\text { hospitals in Japan }\end{array}$ & 2013-2017 & $\begin{array}{l}\text { Elderly patients } \\
\text { with pneumonia }\end{array}$ & 58 & 61 & $\begin{array}{l}\text { Oral sitafloxacin } \\
100 \mathrm{mg} \mathrm{qd}\end{array}$ & $\begin{array}{c}\text { Oral garenoxacin } 400 \mathrm{mg} \\
\text { qd }\end{array}$ \\
\hline
\end{tabular}




\subsection{Clinical Efficacy}

The clinical response rate of sitafloxacin in the treatment of acute bacterial infections at EOT among the CE population was $94.6 \%$, which was similar to that of the comparator (92.5\%) (OR, 1.01; $95 \%$ CI, $0.24-4.32 ; I^{2}=66 \%$ ) (Figure 3 ). The similarity did not differ in the sensitivity analysis. These findings did not change according to oral form (OR, 1.16; 95\% CI, $0.21-6.52 ; I^{2}=73 \%$ ) or intravenous form (OR, 0.50; 95\% CI, 0.04-5.80). The clinical failure rate at EOT of sitafloxacin was only $4.1 \%$, which was similar to that of the comparator $(7.5 \%)\left(\mathrm{OR}, 0.75 ; 95 \% \mathrm{CI}, 0.21-2.65 ; I^{2}=52 \%\right)$. The similarity between sitafloxacin and the comparator was also observed in oral form (OR, 0.73; 95\% CI, 0.16-3.32; $I^{2}=63 \%$ ) or intravenous form (OR, $\left.0.97 ; 95 \% \mathrm{CI}, 0.06-16.18\right)$. Among the ITT population, no significant difference was observed regarding the clinical response rate at EOT $(88.7 \%$ vs. $86.0 \%$, OR, $1.26 ; 95 \% \mathrm{CI}$, $0.69-2.28 ; I^{2}=0 \%$ ). The clinical response rate and clinical failure rate at TOC among the CE population was similar between sitafloxacin and the comparator (clinical response rate: $95.3 \%$ vs. $93.8 \%$, OR, 0.98 ; $95 \%$ CI, $0.41-2.34 ; I^{2}=0 \%$, and clinical failure rate: $4.2 \%$ vs. $4.4 \%$, OR, $1.00 ; 95 \% \mathrm{CI}, 0.40-2.49 ; I^{2}=0 \%$ ).

\begin{tabular}{|c|c|c|c|c|c|c|c|c|c|}
\hline Study or Subgroup & \multicolumn{2}{|c|}{ Experimental } & \multicolumn{2}{|c|}{ Control } & Weight & $\begin{array}{c}\text { Odds Ratio } \\
\text { M-H. Random. } 95 \% \mathrm{Cl}\end{array}$ & & $\begin{array}{c}\text { Odds Ratio } \\
\text { M-H. Random. } 95 \% \mathrm{Cl}\end{array}$ & \\
\hline Feldman et al, 2001 & 31 & 33 & 31 & 32 & $16.9 \%$ & $0.50[0.04,5.80]$ & & & \\
\hline Kawada et al, 2008 & 98 & 102 & 81 & 98 & $27.3 \%$ & $5.14[1.66,15.89]$ & & & \\
\hline Lojanapiwat et al, 2019 & 105 & 108 & 102 & 103 & $18.1 \%$ & $0.34[0.04,3.35]$ & & & \\
\hline Malaisri et al, 2017 & 19 & 19 & 16 & 17 & $12.3 \%$ & $3.55[0.14,93.01]$ & & & \\
\hline Miyazaki et al, 2019 & 47 & 55 & 54 & 57 & $25.3 \%$ & $0.33[0.08,1.30]$ & & & \\
\hline Total $(95 \% \mathrm{Cl})$ & & 317 & & 307 & $100.0 \%$ & $1.01[0.24,4.32]$ & & & \\
\hline Total events & 300 & & 284 & & & & & & \\
\hline $\begin{array}{l}\text { Heterogeneity: } \operatorname{Tau}^{2}=1 \\
\text { Test for overall effect: } z\end{array}$ & $\begin{array}{l}8 ; \mathrm{Chi}^{2}=1 \\
0.01(\mathrm{P}=\end{array}$ & $\begin{array}{l}\text { 1.81, df } \\
0.99)\end{array}$ & $=4(P=C$ & $0.02) ; 1^{2}$ & $2=66 \%$ & & 0.005 & 0.1 & 200 \\
\hline
\end{tabular}

Figure 3. The clinical response rate of sitafloxacin and the comparator in the treatment of acute bacterial infections at the end of treatment visit among the clinical evaluable population.

In the subgroup analysis of cUTI/APN based on three studies $[7,8,11]$ the clinical response rate of sitafloxacin and the comparator was $96.9 \%$ and $91.3 \%$, respectively, and no significant difference between them was observed (OR, 2.08; 95\% CI, 0.35-12.44; $I^{2}=54 \%$ ). For patients with APN in three studies $[7,8,11]$, sitafloxacin exhibited a similar clinical response rate with the comparator (OR, 1.90; $95 \%$ CI, $0.46-7.83 ; I^{2}=0 \%$ ). In the subgroup analysis of pneumonia, the pooled analysis of the two studies [5,9] showed that the clinical response rate of sitafloxacin was $88.6 \%$, which was comparable to that of the comparator (OR, $\left.0.36 ; 95 \% \mathrm{CI}, 0.11-1.21 ; I^{2}=0 \%\right)$.

\subsection{Microbiological Response}

Overall, the microbiological response of sitafloxacin in the treatment of acute bacterial infection was $82.0 \%$, which was similar to that of the comparator $(77.8 \%)\left(\mathrm{OR}, 1.59 ; 95 \% \mathrm{CI}, 0.77-3.28 ; I^{2}=47 \%\right)$ (Figure 4). This finding did not change according to oral form (OR, $1.59 ; 95 \% \mathrm{CI}, 0.70-3.62 ; I^{2}=60 \%$ ) or intravenous form (OR, 1.90; 95\% CI, 0.16-22.72). Subgroup analysis did not find significant difference between sitafloxacin and the comparator for patients with cUTI/APN (OR, 1.77; 95\% CI, 0.57-5.56; $I^{2}=73 \%$ ) and pneumonia (OR, $\left.1.33 ; 95 \% \mathrm{CI}, 0.45-3.93 ; I^{2}=0 \%\right)$. 


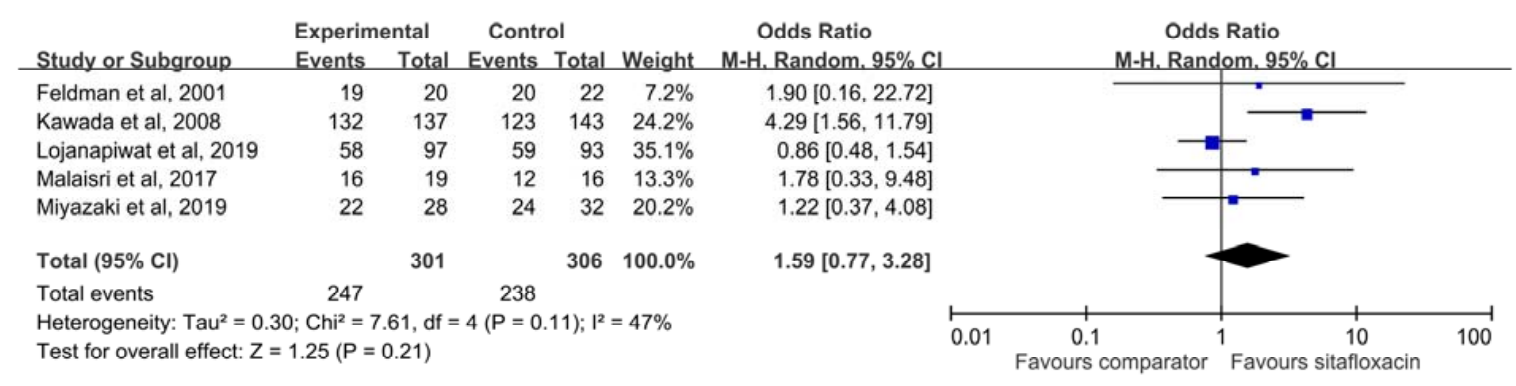

Figure 4. The microbiological response rate of sitafloxacin and the comparator for treating acute bacterial infections.

\subsection{Risk of Adverse Event}

Four studies $[5,7,9,11]$ reported the risk of treatment-emergent adverse event (TEAE), and we found the risk of TEAE was similar between sitafloxacin and the comparator (OR, 1.14; 95\% CI, $\left.0.64-2.01 ; I^{2}=61 \%\right)$. Three studies $[5,7,9]$ reported the risk of drug-related TEAE, and the risk of sitafloxacin-related TEAE was similar to that of the comparator $(14.4 \%$ vs. $12.9 \%$, OR, $1.14 ; 95 \%$ CI, $0.48-2.69 ; I^{2}=56 \%$ ). In the pooled analysis of three studies $[5,7,8]$ reported mortality, the all-cause mortality of sitafloxacin was $0.49 \%$, which was as low as that of the comparator $(0.49 \%)(\mathrm{OR}, 0.93 ; 95 \%$ CI, $\left.0.09-9.44 ; I^{2}=2 \%\right)$.

\section{Discussion}

This meta-analysis investigating the use of sitafloxacin in the treatment of acute bacterial infections has several significant findings. First, sitafloxacin exhibited a similar clinical response and failure rate with the comparators at EOT among the CE population. Second, the similarity between sitafloxacin and the comparator was also revealed in many ways, such as the clinical efficacy at the TOC visit, clinical response rate among the ITT population, and sensitivity analysis. Third, the subgroup analysis demonstrated that the clinical response rates of sitafloxacin in the treatment of cUTI/APN, only APN, and pneumonia were comparable to the comparators. Finally, the microbiological response rate between sitafloxacin and the comparator was similar in the pooled analysis of five RCTs and even the subgroup analysis of cUTI/APN and the pneumonia group. Therefore, these findings suggest that the clinical efficacy of sitafloxacin is comparable to other antibiotics in the treatment of acute bacterial infection.

In addition to these clinical findings, four enrolled studies [7-9,11] in this meta-analysis demonstrated the sitafloxacin exhibited potent in vitro activity. In the Lojanapiwat et al. study [7], the antibiotic-resistant rate of sitafloxacin was only 5.9\% (17/289), which was lower than the comparators (ceftriaxone: $10.7 \%$, and cefdinir, $12.1 \%$ ). In the Kawada et al study [11], the $\mathrm{MIC}_{50}$ and $\mathrm{MIC}_{90}$ of sitafloxacin was lower than levofloxacin ( $\mathrm{MIC}_{50}: 0.1 \mu \mathrm{g} / \mathrm{mL}$ vs. $0.78 \mu \mathrm{g} / \mathrm{mL}, \mathrm{MIC}_{90}: 1.56 \mu \mathrm{g} / \mathrm{mL} \mathrm{vs} . \geq$ $25 \mu \mathrm{g} / \mathrm{mL}$ ). In the Miyazaki et al. study [9], the MICs of sitafloxacin against most of the Gram-negative bacteria were lower than those of garenoxacin. Even for ESBL-producing pathogens, the sitafloxacin resistant rate was only 5.6\% (2/36) in Malasiri et al.'s study [8]. All these findings were consistent with previous studies $[4,13-16]$ and confirmed the potent in vitro activity of sitafloxacin. Therefore, the favorable clinical efficacy of sitafloxacin in the treatment of acute bacterial infections may be partially explained by the findings of these in vitro studies.

We also found that the risk of $\mathrm{AE}$ among patients receiving sitafloxacin was as low as other comparative agents in this meta-analysis. The risks of TEAE, drug-related TEAE, and all-cause mortality did not differ between sitafloxacin and the comparators. Therefore, it should suggest that sitafloxacin was as tolerable as the comparator in the clinical uses.

This meta-analysis has several limitations. First, most of the included studies were conducted in Asia, particularly Japan and Thailand, and the number of enrolled patients and study were limited. Therefore, the finding of this meta-analysis may not be generalized to Western countries. Second, the 
dosage of sitafloxacin varied in different studies, which may affect the clinical efficacy and safety of this novel agent. Third, only two types of infections-cUTI/APN and pneumonia were included in this meta-analysis. Although these two types of infections are the most common type of infection in the real world, we still need further studies to explore the use of sitafloxacin in other types of infections.

In conclusion, sitafloxacin is noninferior to other comparators in both clinical and microbiological response rates for treating patients with an acute bacterial infection. Furthermore, sitafloxacin is as tolerable as the comparators.

Author Contributions: Conceptualization, C.-K.C., I.-L.C., and C.-C.L.; data curation, I.-L.C., Y.H.C., and C.-C.L.; formal analysis, C.-K.C., I.-L.C., and Y.-H.C.; investigation, I.-L.C. and Y.-H.C.; supervision, C.-C.L.; writing-original draft, C.-K.C.; writing-review and editing, C.-C.L. All authors have read and agreed to the published version of the manuscript.

Funding: This research received no external funding.

Conflicts of Interest: The authors declare no conflict of interest.

\section{References}

1. Keating, G.M. Sitafloxacin: In bacterial infections. Drugs 2011, 71, 731-744. [CrossRef] [PubMed]

2. Amano, A.; Matsuzaki, K.; Kishi, N.; Koyama, H.; Hasegawa, M.; Ikeda, F.; Yamaguchi, H.; Yokomizo, A.; Mizuno, M. In vitro activity of sitafloxacin against clinical isolates in 2012. Jpn. J. Antibiot. 2013, 66, 311-330. [PubMed]

3. Amano, A.; Kishi, N.; Koyama, H.; Matsuzaki, K.; Matsumoto, S.; Uchino, K.; Yamaguchi, H.; Yokomizo, A.; Mizuno, M. In vitro activity of sitafloxacin against atypical bacteria (2009-2014) and comparison between susceptibility of clinical isolates in 2009 and 2012. Jpn. J. Antibiot. 2016, 69, 131-142. [PubMed]

4. Huang, Y.S.; Wang, J.T.; Sheng, W.H.; Chuang, Y.C.; Chang, S.C. Comparative in vitro activity of sitafloxacin against bacteremic isolates of carbapenem resistant Acinetobacter baumannii complex. J. Microbiol. Immunol. Infect. 2015, 48, 545-551. [CrossRef] [PubMed]

5. Feldman, C.; White, H.; O'Grady, J.; Flitcroft, A.; Briggs, A.; Richards, G. An open, randomised, multi-centre study comparing the safety and efficacy of sitafloxacin and imipenem/cilastatin in the intravenous treatment of hospitalised patients with pneumonia. Int. J. Antimicrob. Agents 2001, 17, 177-188. [CrossRef]

6. Fujita, J.; Niki, Y.; Kadota, J.; Yanagihara, K.; Kaku, M.; Watanabe, A.; Aoki, N.; Hori, S.; Tanigawara, Y.; Cash, H.L.; et al. Clinical and bacteriological efficacies of sitafloxacin against community-acquired pneumonia caused by Streptococcus pneumoniae: Nested cohort within a multicenter clinical trial. J. Infect. Chemother. 2013, 19, 472-479. [CrossRef] [PubMed]

7. Lojanapiwat, B.; Nimitvilai, S.; Bamroongya, M.; Jirajariyavej, S.; Tiradechavat, C.; Malithong, A.; Predanon, C.; Tanphaichitra, D.; Lertsupphakul, B. Oral sitafloxacin vs. intravenous ceftriaxone followed by oral cefdinir for acute pyelonephritis and complicated urinary tract infection: A randomized controlled trial. Infect. Drug Resist. 2019, 12, 173-181. [CrossRef] [PubMed]

8. Malaisri, C.; Phuphuakrat, A.; Wibulpolprasert, A.; Santanirand, P.; Kiertiburanakul, S. A randomized controlled trial of sitafloxacin vs. ertapenem as a switch therapy after treatment for acute pyelonephritis caused by extended-spectrum beta-lactamase-producing Escherichia coli: A pilot study. J. Infect. Chemother. 2017, 23, 556-562. [CrossRef] [PubMed]

9. Miyazaki, T.; Nakamura, S.; Hashiguchi, K.; Kobayashi, T.; Fukushima, K.; Fukuda, Y.; Kondo, A.; Inoue, Y.; Koga, H.; Sasaki, E.; et al. The efficacy and safety of sitafloxacin and garenoxacin for the treatment of pneumonia in elderly patients: A randomized, multicenter, open-label trial. J. Infect. Chemother. 2019, 25, 886-893. [CrossRef] [PubMed]

10. Shetty, N.; Wilson, A.P. Sitafloxacin in the treatment of patients with infections caused by vancomycin-resistant enterococci and methicillin-resistant Staphylococcus aureus. J. Antimicrob. Chemother. 2000, 46, 633-638. [CrossRef] [PubMed]

11. Kawada, Y.; Matsui, T.; Matsui, T.; Tsugawa, M.; Mastumoto, T.; Nakashima, M. Comparative study on sitafloxacin and levofloxacin in complicated urinary tract infections. Jpn. J. Chemother. 2008, 56, 81-91. 
12. Higgins, J.P.; Altman, D.G.; Gotzsche, P.C.; Juni, P.; Moher, D.; Oxman, A.D.; Savovic, J.; Schulz, K.F.; Weeks, L.; Sterne, J.A.; et al. The Cochrane Collaboration's tool for assessing risk of bias in randomised trials. BMJ 2011, 343, d5928. [CrossRef] [PubMed]

13. Tateda, K.; Ohno, A.; Ishii, Y.; Murakami, H.; Yamaguchi, K.; Levofloxacin Surveillance Group. Investigation of the susceptibility trends in Japan to fluoroquinolones and other antimicrobial agents in a nationwide collection of clinical isolates: A longitudinal analysis from 1994 to 2016. J. Infect. Chemother. 2019, 25, 594-604.

14. Dong, X.; Chen, F.; Zhang, Y.; Liu, H.; Liu, Y.; Ma, L. In vitro activities of sitafloxacin tested alone and in combination with rifampin, colistin, sulbactam, and tigecycline against extensively drug-resistant Acinetobacter baumannii. Int. J. Clin. Exp. Med. 2015, 8, 8135-8140. [PubMed]

15. Nakamura, T.; Komatsu, M.; Yamasaki, K.; Fukuda, S.; Higuchi, T.; Ono, T.; Nishio, H.; Sueyoshi, N.; Kida, K.; Satoh, K.; et al. Susceptibility of various oral antibacterial agents against extended spectrum beta-lactamase producing Escherichia coli and Klebsiella pneumoniae. J. Infect. Chemother. 2014, 20, 48-51. [CrossRef] [PubMed]

16. Yamaguchi, K.; Ohno, A.; Ishii, Y.; Tateda, K.; Iwata, M.; Kanda, M.; Tsujio, Y.; Kimoto, H.; Kaimori, M.; Nakamura, T.; et al. In-vitro susceptibilites to levofloxacin and various antibacterial agents of 18,639 clinical isolates obtained from 77 centers in 2004. Jpn. J. Antibiot. 2006, 59, 428-451. [PubMed]

(C) 2020 by the authors. Licensee MDPI, Basel, Switzerland. This article is an open access article distributed under the terms and conditions of the Creative Commons Attribution (CC BY) license (http://creativecommons.org/licenses/by/4.0/). 